\title{
THE 1992 PJVA MODEL FORM UNIT AGREEMENT
}

\section{DAVID A. GUICHON, JR.}

The writer discusses the development and content of the 1992 Petroleum Joint Venture Association (PJVA) Model Form Unit Agreement. This model agreement is intended to update and replace the 1972 Model in a systematic and thorough manner. The author highlights and explains significant new provisions of the 1992 Model. A copy of the full 1992 Model Form is included as an appendix for reference.

\section{TABLE OF CONTENTS}

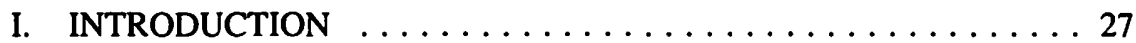

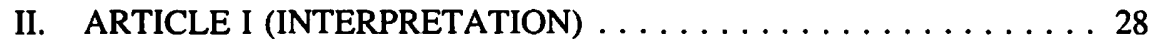

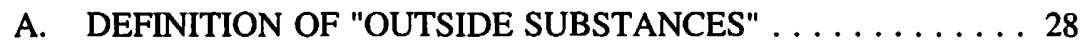

B. DEFINITION OF "PETROLEUM SUBSTANCES" . . . . . . . . . . . . . . 29

C. DEFINITION OF "ROYALTY INTEREST" . . . . . . . . 29

D. DEFINITIONS OF "UNIT OPERATIONS"

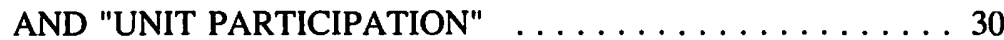

E. DEFINITION OF "WORKING INTEREST" $\ldots \ldots \ldots \ldots \ldots 30$

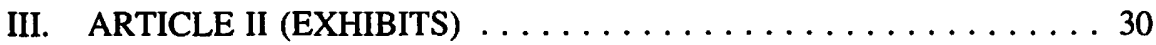

IV. ARTICLE III (UNITIZATION AND EFFECTS) $\ldots \ldots \ldots \ldots \ldots 31$

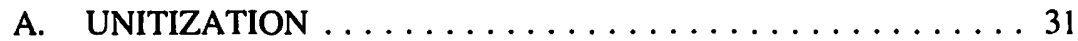

B. CONTINUATION OF LEASES $\ldots \ldots \ldots \ldots \ldots \ldots \ldots \ldots \ldots$

C. EXTRANEOUS DEFAULTS $\ldots \ldots \ldots \ldots \ldots \ldots \ldots \ldots \ldots$

D. EFFECT OF UNITIZATION OF TITLES $\ldots \ldots \ldots \ldots \ldots 31$

V. ARTICLE VII (ALLOCATION OF

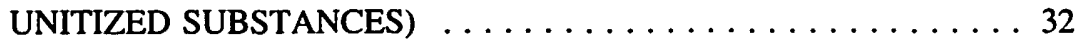

A. ALLOCATION OF PRODUCTION $\ldots \ldots \ldots \ldots \ldots \ldots \ldots 32$

B. CALCULATION AND

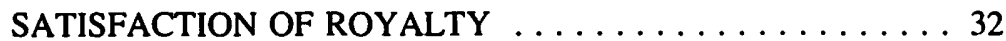

C. OBLIGATION TO TAKE IN KIND $\ldots \ldots \ldots \ldots \ldots \ldots \ldots 33$

VI. ARTICLE IX (APPROVAL AND

WARRANTY OF TITLES) $\ldots \ldots \ldots \ldots \ldots \ldots \ldots \ldots \ldots \ldots \ldots \ldots \ldots$

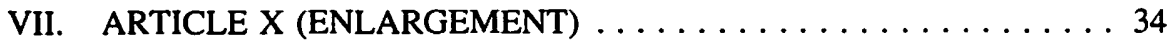

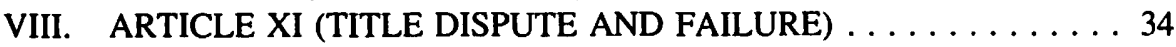

IX. ARTICLE XII (CHANGES IN INTEREST) $\ldots \ldots \ldots \ldots \ldots \ldots 35$

$\mathrm{X}$. ARTICLE XIV (TERMINATION) $\ldots \ldots \ldots \ldots \ldots \ldots \ldots \ldots \ldots$

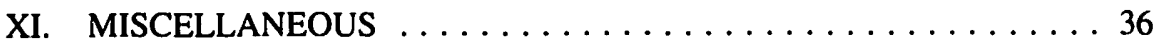

A. FORCE MAJEURE (CLAUSE 1507) $\ldots \ldots \ldots \ldots \ldots \ldots 36$

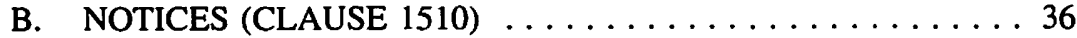

XII. CONCLUSION $\ldots \ldots \ldots \ldots \ldots \ldots \ldots \ldots \ldots \ldots \ldots \ldots \ldots \ldots \ldots \ldots$

APPENDIX PJVA MODEL FORM $\ldots \ldots \ldots \ldots \ldots \ldots \ldots$ 


\section{INTRODUCTION}

The first Canadian model form of Unit Agreement, commonly referred to as the "Mines Ministers' Model" was developed on behalf of the Petroleum and Natural Gas Committee of the Annual Conference of Provincial Mines Ministers and was originally adopted by that Committee in 1962. The Mines Ministers' Model was revised from time to time between 1962 and 1972 but has not been officially revised since the 1972 Conference. By the mid-'80s, a number of the provisions contained in the 1972 version of the Mines Ministers' Model (the "1972 Model") were being modified on an ad hoc basis to reflect changing industry needs and views, and in 1986, the Petroleum Joint Venture Association formed a task force (the "Task Force") to review the 1972 Model and generate an updated Alberta model that would be acceptable to both industry and Alberta Energy (the "Crown"). The author joined the Task Force shortly after it was formed and has been involved with it ever since.

The mandate of the Task Force was to produce a model that both industry and the Crown would endorse and use, and the fulfilment of that mandate proved to be a more arduous and time consuming undertaking than had originally been anticipated by either the PJVA Board of Directors or the Task Force. The Task Force commenced the process by reviewing the 1972 Model and effecting preliminary revisions aimed at clarifying certain concepts and modifying others to reflect the Task Force's understanding of the most appropriate or accepted approach to various "business" issues. Drafts of the revised model were then circulated to the Crown and the PJVA Board of Directors for review and discussion on an ongoing basis, until the refinement of the model had advanced to a point at which it could be circulated for general review. In May of 1988, a draft of the model was distributed to the Canadian Petroleum Law Foundation and the general PJVA membership as well as the core review group, and all recipients of the draft were asked to provide their comments thereon. The resultant comments were reviewed, assessed and, in many cases, adopted by the Task Force, and a new round of discussions among the Task Force, the Crown and the PJVA Board of Directors ensued, with PanCanadian Petroleum Limited eventually joining the core review group as a party having a particular interest in the rights of freehold royalty owners. Given the number and types of parties having vested interests in the terms of the model, numerous additional rounds of negotiation and drafting were required to produce a document that the Task Force felt reconciled the often divergent views of the review participants on the proper treatment of various issues.

The Task Force was finally able to submit a recommended model form of Unit Agreement to the PJVA Board of Directors in early March 1992, and this model was approved and adopted by the Board on March 17. This model also received the official approval of the Crown in late May. A few modifications have since been made to the model to deal with some additional concerns raised by PanCanadian and the Crown, and although neither the PJVA nor the Crown have yet officially approved these modifications, it is anticipated that such approvals will be forthcoming shortly, and that the modifications will be incorporated in the first version of the model to be circulated for general use. 
A copy of the modified version of the model (the "1992 Model") is appended to this article for reference. A number of the terms defined in the 1992 Model are used in the article without any separate definition.

The purpose of this paper is simply to highlight some of the more significant differences between the 1972 Model and the 1992 Model, and to note some of the issues that proved to be contentious or otherwise focal in the review and consultation process that led to the generation of the 1992 Model. The paper is not intended to be a treatise on legal principles of relevance to unitization, nor is it intended to be a comprehensive compendium of all of the changes that have been made to the 1972 Model. Rather, it is intended only to be a general commentary touching on items which the author considered to be of potential general interest or consequence to practitioners of Alberta oil and gas law. Those items are as follows:

\section{ARTICLE I (INTERPRETATION)}

\section{A. DEFINITION OF "OUTSIDE SUBSTANCES" (SUBCLAUSE 101(e))}

The definition of "Outside Substances" contained in the 1992 Model is really only appropriate for use in units comprised entirely of Crown lands, but the Crown felt very strongly about having this definition in the Model, and it was accordingly adopted to facilitate finalization of the Model.

The Crown is concerned with the treatment of what it refers to as "royalty-waived" substances, which are in fact "royalty-deferred" substances in the sense that the Crown permits them to be produced from one location for injection into another location with no royalty becoming payable until the substances are ultimately recovered for sale from the second location. The Crown has advised that it is not set up to monitor the movement and ultimate recovery of these royalty-deferred injectants, so its practice is to permit the royalty deferral arrangement only where the unit into which the substances are to be injected is $100 \%$ Crown, and where the production location and the injection location have the same royalty characteristics (i.e., the same ownership, the same new/old gas classification, etc.). This way the Crown can permit the injected substances to be produced from the unit as native substances without worrying about any adverse effect on the amount of royalty ultimately recovered by the Crown. The definition of "Outside Substances" contained in the 1992 Model facilitates this arrangement, and is suitable in a $100 \%$ Crown unit situation. In a freehold or mixed Crown/freehold situation, however, the Crown's preferred definition unduly restricts the flexibility of freehold Working Interest Owners. Under many freehold leases the lessee is entitled to use leased substances in injection operations without paying any royalty on such substances until they are ultimately recovered for sale. If the Crown's preferred definition was used for a unit involving freehold lands, the result would be either that the freehold Working Interest Owners would have to pay immediate royalty on non-unitized injectants obtained from the freehold lands, or that such non-unitized injectants would become Unitized Substances upon injection, with the result that the individual proprietary rights of the contributing Working Interest Owner and its Royalty Owner would be forfeited to the unit. 
An alternative definition of "Outside Substances" more suitable to a freehold or mixed Crown/freehold situation will be included in the guide notes to be circulated with the 1992 Model. If the Crown will not permit the use of such an alternative definition in these situations, side agreements may have to be entered into with freehold Royalty Owners in any circumstances in which injectants are being obtained from non-unitized formations in freehold lands within a Unit Area.

\section{B. DEFINITION OF "PETROLEUM SUBSTANCES" (SUBCLAUSE 101(g))}

The definition of "Petroleum Substances" contained in the 1992 Model is intended for use in connection with a combined oil and gas unit, and is a relatively straightforward definition. The selection of an appropriate alternative definition for use in connection with an oil-only or gas-only unit, however, may be complicated in a mixed Crown/freehold unit situation by the different bases for distinguishing petroleum from natural gas in freehold and Crown properties. In the case of a freehold property, the Privy Council decision in Borys v. C.P.R. and Imperial Oil' suggests that, absent a contrary intention, the characterization of production as either petroleum or natural gas will depend on whether the product in question was in a liquid or gaseous state in the reservoir. In the case of a Crown property on the other hand, subsection 90(2) of the Mines and Minerals Act, R.S.A. 1980 c. M-15 distinguishes petroleum production from natural gas production on the basis of the initial GOR of the well from which the relevant production is obtained. ${ }^{2}$ The safe bet would accordingly seem to be to define the substance to be unitized as broadly as possible, so as to ensure that it is covered in both Crown and freehold situations, but the question of the relative value to be ascribed to incidentally unitized substances is bound to complicate the tract factor allocation process, particularly in situations where the rights to petroleum and natural gas are split.

\section{DEFINITION OF "ROYALTY INTEREST" (SUBCLAUSE 101(h))}

The definition of "Royalty Interest" contained in the 1992 Model has been criticized as unnecessarily complex, but the Task Force has revisited the definition on numerous occasions and remains of the view that it is appropriate. The reason for distinguishing between mineral ownership interests and production/revenue royalty interests is twofold: firstly, to emphasize that a lessor royalty right is severable from the base ownership interest (certain types of royalty trust arrangements being examples of this ${ }^{3}$ ), and, secondly, to make it clear that overriding royalty interests and similar encumbrances are

(1953), 7 W.W.R. (NS) 546.

Although the as yet unreported Reasons for Judgment in Prism Petroleum Lid. et.al. v. Omega Hydrocarbons Ltd. (Alberta Court of Queen's Bench Action No. 8901-03958) express the view that the purpose of a predecessor to subsection 90(2) was simply "to define, for conservation purposes, what is a gas well and what is an oil well" (p. 29), and that the subsection "has nothing whatsoever to do with determining ownership of oil or gas" (p. 30), it is respectfully submitted that this view is incorrect, and fails to take into account the proper meaning of the term "disposition" as used in the predecessor subsection.

3. The fact situation in Voyager Petroleums v. Vanguard Petroleums Lud. et.al. (1983), 27 Alta L.R. (2d) 1 (Q.B.) exemplifies the complications that may arise when the severability of these rights and interests is not given due consideration. 
intended to be included in the definition along with lessor royalty interests. A number of companies expressed the view that overriding royalty and similar interests should not be considered Royalty Interests, but the more prevalent preference was to cast a fairly wide net in this respect. Because clause 502 of the Model provides latitude to proceed without all Royalty Interest owners having become Parties, it was thought that it would be preferable to define Royalty Interests broadly and then assess individual importance on a case-by-case basis.

It should be kept in mind when providing advice on the satisfaction of clause 502 qualification requirements that the exclusion of security interests from the definitions of "Royalty Interest" and "Working Interest" does not mean that they can be ignored. They are still interests which will have to be dealt with for purposes of ensuring the priority of the unitization arrangement.

\section{DEFINITIONS OF "UNIT OPERATIONS" AND "UNIT PARTICIPATION" (SUBCLAUSES 101(n) and (p))}

The definitions of "Unit Operations" and "Unit Participation" are new definitions which were inserted for purposes of improving certainty and simplifying drafting. Both terms are typically used as defined terms in unit operating agreements, and it was felt that it would be helpful to use them in the Model as well.

\section{E. DEFINITION OF "WORKING INTEREST" (SUBCLAUSE 101(s))}

As was the case with the definition of "Royalty Interests," the definition of "Working Interest" contained in the 1992 Model initially came under considerable fire for being too complex and an unnecessary departure from the definition contained in the 1972 Model. The Task Force acknowledged the attractiveness of the simplicity of the old definition, but thought it important to use the definition to clarify a number of points, including the facts that (i) a fee simple interest will be considered a Working Interest if it is not subject to a Lease, (ii) a Working Interest need not be the gross right to produce and dispose of hydrocarbon substances, but just an interest therein, (iii) a carried working interest is still a Working Interest notwithstanding that it is not chargeable with drilling or other costs, and (iv) an overriding or lessor royalty is not a Working Interest notwithstanding that it may be chargeable with processing, transportation and disposition costs. The clarification of some of these points seemed particularly significant in light of the fact that the definition of "Royalty Interest" specifically excludes Working Interests.

\section{ARTICLE II (EXHIBITS)}

Because exhibits are deemed to be correct and binding from the time at which they become effective, it was necessary to establish a workable arrangement under which exhibit errors could be corrected without significant adverse consequence to any of the parties affected thereby. Clause 202 and subclause 203(c) are intended to establish such an arrangement. 


\section{ARTICLE III (UNITIZATION AND EFFECT)}

\section{A. UNITIZATION (CLAUSE 301)}

The words "as if the Unitized Zone had been included in a single Lease..." were deleted from this clause because it was not clear precisely what those words were intended to mean.

\section{B. CONTINUATION OF LEASES (CLAUSE 302)}

This clause (formerly clause 303) was modified to provide that unitized leases are maintained in force and effect by the subsistence of the unitization arrangement, as opposed to the conduct of Unit Operations. The words "as if a well had been drilled to" were added to the clause to cover unless-type Leases which are still in their primary term. A new proviso was also added to the clause to address concerns with respect to the obligation to pay shut-in royalties in the absence of actual production.

\section{EXTRANEOUS DEFAULTS (CLAUSE 303)}

Clause 303 is a new clause which recognizes that the rights granted by a Lease may be split among different parties on a zonal basis, and addresses the concern of a termination of unitized rights being triggered by a default relating only to non-unitized rights.

\section{EFFECT OF UNITIZATION ON TITLES (CLAUSES 302, 304 AND 306)}

Clause 306 makes it clear that unitization does not give rise to a cross-conveyance of interests in the Leases or the Tracts, but beyond that there is no clear statement as to what, if any, in rem interests are intended to be granted or created by unitization. The issue is of course important to the question of whether a unit agreement binds subsequent holders of interests in the lands that are subject thereto. Section 149 of the Mines and Minerals Act, supra provides that a unit agreement entered into by the Crown binds the Crown minerals affected by the agreement, as well as all interests in such minerals, but the case with respect to freehold mineral interests is less certain.

Section 53 of the Land Titles Act, R.S.A. 1980, c. L-5, permits the filing of a unit agreement and the endorsement of a memorandum thereof on the certificates of title for the lands specified therein as being subject thereto, but does not state that such filing and endorsement provides any particular priority protection. Section 57 of the Act states that registration of an instrument "creates, transfers, surrenders, charges or discharges, as the case may be, the land or the estate or interest therein mentioned in the instrument." A unit agreement would presumably therefore have to grant or create an estate or interest in the lands to which it relates in order for its registration under section 53 to have any substantial effect in terms of priority protection. On the basis of the Alberta Court of 
Appeal decision in Esso Resources Canada Ltd. v. Pacific Cassiar Ltd., it is probable that a unit agreement in the form of the 1992 Model would amend most freehold Leases sufficiently to create the "new rights" necessary to give some teeth to a registration under section 53, but it is not entirely clear either that those "new rights" are created in favour of the unit participants as a whole, as opposed to just the lessee under the Lease, or that the "new rights" reasoning would apply if a freehold Lease were found to contain an enforceable unitization clause authorizing the lessee thereunder to bind the leased lands to the terms of a unit agreement entered into by that lessee. ${ }^{s}$

The Task Force considered inserting a provision confirming that unitization is intended to have the effect of creating in rem interests in favour of the unit participants as a whole, but was concerned that the insertion of such a provision in the 1992 Model might give rise to adverse implications with respect to the intention of existing unit agreements which do not contain such a provision. Having regard to the number of unit agreements already in existence, the Task Force was of the view that the matter might more appropriately be dealt with by the enactment of a statutory provision along the lines of section 59.1 of the Law of Property Act, R.S.A. 1980 c.L-8, dealing with rights of first refusal and assignments of rent.

\section{ARTICLE VII (ALLOCATION OF UNITIZED SUBSTANCES)}

\section{A. ALLOCATION OF PRODUCTION (CLAUSE 702)}

Clause 702 has been revised to provide both a more definitive basis for determining the proper allocation of production among Working Interests Owners (the 1972 Model provided that the production allocated to a Tract was to be "distributed ... or accounted for in the same manner ... as though [it] had actually been produced therefrom by the Working Interest Owners"), and an express recognition of Royalty Owner rights to take in kind.

\section{B. CALCULATION AND SATISFACTION OF ROYALTY (CLAUSES 703 AND 704)}

Clause 703 of the 1972 Model has been split into two clauses, being clauses 703 and 704 of the 1992 Model. The new clause 703 addresses some issues not previously addressed, such as minimum royalty obligations, the calculation of sliding scale royalties based on individual well production volumes, and the paramountcy of the royalty regulations under the Mines and Minerals Act, supra in the case of Crown royalties. The

(1986), 45 Alta L.R. (2d) 1.

s. The as yet unreported Reasons for Judgment in Prism Petroleum Ldd. et.al. v. Omega Hydrocarbons $L d$. (supra note 2 ) seem to suggest that the unit agreement under consideration in that case created in rem interests in favour of at least the Working Interest Owners thereunder (at 17-21), but no support for, or explanation of, this apparent conclusion is given, and the uncertainty in the matter is exacerbated by a late inning statement to the effect that Omega was bound by the unit agreement by virtue of having recognized its "existence and applicability" in a title quieting agreement (at 21 ). All in all, the treatment of the issue in this decision is very unsatisfactory. 
new clause 704 makes it clear that, except in very limited circumstances, Royalty Owners are not entitled to look to the Working Interest Owners as a whole for any default in royalty obligations on the part of an individual Working Interest Owner.

\section{OBLIGATION TO TAKE IN KIND (CLAUSE 705)}

Clause 705 of the 1992 Model combines the concepts addressed in clauses 704 and 705 of the 1972 Model, and clarifies the intention that de jure possession of, and responsibility for, each Working Interest Owner's share of unit production vests in that Working Interest Owner upon production. Aside from reflecting the general industry practice in this respect, the confirmation of this arrangement is of relevance in that the grounds for suggesting that unitization gives rise to a partnership are arguably less substantial if the joint undertaking of the Working Interest Owners is limited as much as possible to the cooperative exercise of correlative real property rights.

The new clause 705 introduces the concept of an Exhibit "D" setting forth a procedure for dealing with a Working Interest Owner's failure to make adequate arrangements for the disposition of its share of unit production. Clause 705 of the 1972 Model stipulated that such production was to be disposed of by the Unit Operator, but with the advent of proposals for balancing and banking arrangements, it was felt that the use of an exhibit to deal with failure-to-take matters would provide flexibility to negotiate whatever arrangements might seem appropriate in the circumstances without requiring any significant revision of the model itself.

Instead of using the traditional failure-to-take language, the new clause 705 imposes an obligation to make appropriate "disposition arrangements" and provide the Unit Operator with advance notice thereof, failing which the relevant remedial provisions become applicable. The remedial provisions also become applicable if a Working Interest Owner's disposition arrangements "are inadequately provided for or are otherwise unworkable or impracticable." Although there was some initial resistance to the introduction of this latter concept due to a concern about the potential for Unit Operator abuse, the prevailing view was that the provision simply expresses an understanding that is already implicit, and provides a more defined means of dealing with the situation.

\section{ARTICLE IV (APPROVAL AND WARRANTY OF TITLES)}

Articles IX, X and XI of the model have been reorganized so that title approval and warranty matters are now dealt with before enlargement and title dispute and failure matters. This change was simply a housekeeping type of change that was intended to provide for a more logical sequence of occurrence for the concepts dealt with by these Articles.

Article IX of the 1992 Model provides for both a title review process and a warranty of title in respect of all Working Interests. The Task Force's view with respect to title risk was that no Party should be exposed to liability or loss resulting from a deficiency in another Party's title, and that the basic objective of Article IX should accordingly be to minimize the risk of any such exposure. Although provision for both title review and 
title warranty may be considered to be a 'belt and suspenders' approach to the matter, the thought was that the title review process should be used to minimize the risk of unidentified title concerns beforehand, while the title warranty provisions make it clear that any Working Interest title problems which do arise are intended to be the responsibility of the Party purporting to contribute the deficient Working Interest to the unit. The Task Force recognizes that this approach to the matter may not be considered appropriate in all circumstances, and the guide notes to the Model will offer alternative approaches to the matter, including an alternative form of warranty that accommodates the recognition of Working Interests which are held on behalf of 'silent' participants.

In the case of Royalty Interests, provision is made for title review, but not for a warranty of title. The prevailing view in this respect was that owners of fee simple and similar freehold ownership Royalty Interests would probably balk at being asked to provide a warranty of title, and that a sufficient level of comfort in this respect should be obtainable through the conduct of the Land Titles Office and Alberta Energy searches.

A couple of clarification changes that were made to Article IX were, firstly, the inclusion of a statement to the effect that the approval of a title notwithstanding knowledge of subsisting or prospective deficiencies therein is not to be construed as an acceptance of or acquiesence in any such deficiencies, and, secondly, the inclusion of an acknowledgement that the term "failure of title" includes the cancellation, surrender or other loss of a Lease.

\section{ARTICLE X (ENLARGEMENT)}

The enlargement provisions of the 1972 Model contemplated an "application" for enlargement being made by the owners of the Working Interests in the enlargement lands, but clauses 1001 and 1002 of the 1992 Model have been re-worded to recognize that an enlargement proposal may arise in a number of ways, and that the proposal, including the associated re-allocation of Tract Participations, is a matter for the Working Interest Owners as a whole to consider and approve, disapprove or re-formulate as they see fit.

Clause 1006 of the 1992 Model is a new provision which effectively prohibits enlargements where the Working Interests in both the Unit Area and the enlargement area are all owned by a single entity or a group of affiliated entities. This provision was inserted at the request of the Crown because it wanted to ensure that a single Working Interest Owner, or group of affiliated owners of Working Interests, could not be left in a position to manipulate Tract Participations in an enlargement situation.

\section{ARTICLE XI (TITLE DISPUTE AND FAILURE)}

Article XI of the 1992 Model generated more comments, and was more contentious, than any other part of the Model. Although the Task Force did not set out to create a fifteen clause Article comprising roughly one quarter of the text of the Model, and in fact made a conscious effort to minimize detail wherever practicable, it found that the provisions required to properly express both the applicable principles and the mechanics for giving effect thereto resulted in a very lengthy and complex Article. 
The two basic principles that the Task Force started with in formulating the provisions of Article XI were, first, that no Party which is not involved in a title dispute should be adversely affected thereby, and, second, that all reasonable efforts should be made to protect against a title failure resulting in an unwanted 'window' in a unit.

Clauses 1101 through 1107 attempt to establish a set of mechanics through which the economic rights of the various parties claiming an interest in or in respect of the unit production allocable to a disputed Working Interest can be 'protected' pending either the resolution of the title dispute or the establishment of a satisfactory alternate protection arrangement by one or more of such parties. The 1972 Model provided simply for the withholding and sale of such production, without, among other things, dealing with the satisfaction of royalty obligations in respect thereof during the period of dispute. Clauses 1104 through 1107, as well as Clause 1112, of the 1992 Model recognize the need to deal with Royalty Owner concerns in a title dispute situation, and attempt to strike a reasonable balance between the need to alleviate those concerns and the need to protect the interests of the unit participants as a whole.

Clauses 1107 through 1111 deal with the various alternative means of protecting against the occurrence of an unwanted 'window' in a unit as a result of a Working Interest title failure. As with the other provisions of Article XI, these clauses were the subject of considerable negotiation and revisitation.

\section{ARTICLE XII (CHANGES IN INTERESTS)}

Clause 1201 of the 1992 Model has been re-worked to expand on and clarify both the definition of "disposition" and the documentation required to be provided to the Unit Operator in respect of a disposition. Clause 1202 is a new provision that was inserted to provide for the recognition of Party changes occurring other than by way of a disposition.

\section{ARTICLE XIV (TERMINATION)}

The termination provisions of the 1972 Model (clause 1502) provided for termination on the basis of either the abandonment or disposition of all formerly productive unit wells, or the termination of the Unit Operating Agreement. Clause 1401 of the 1992 Model provides for termination on the basis of (i) the decision of the Working Interest Owners to terminate, (ii) the abandonment and disposition of all formerly productive unit wells or (iii) the election of a Party to terminate on the basis of unit inactivity.

Clause 1402 establishes the rules for termination on the basis of unit inactivity, and was inserted at the request of the Crown and PanCanadian in order to avoid the unwarranted continuation of inactive units. Although the earlier drafts of this clause attempted to make allowance for inactivity that was due to lack-of-market considerations, no consensus could be reached with respect to the proper parameters for a lack-of-market exception, and it was eventually decided that the most appropriate means of dealing with the matter would be to provide for the setting of specified maximum inactivity periods on a unit-by-unit 
basis, with the Parties being able to take into consideration the particular characteristics of the unit at the time the periods are set.

\section{MISCELLANEOUS}

\section{A. FORCE MAJEURE (CLAUSE 1507)}

Primarily because of the importance of the fit of the force majeure provisions with the new clause 1402 , clause 1507 has been modified to clarify the intention that an event of force majeure is not just something that prevents the performance of obligations, but also something that prevents the conduct of Unit Operations.

\section{B. NOTICES (CLAUSE 1510)}

Clause 1510 is a new provision that was inserted to deal with the mechanics and rules for giving notices under and in respect of the Unit Agreement.

\section{CONCLUSION}

The fact that it took almost six years to reach a consensus on the terms of the 1992 Model speaks to the difficulty of the task of producing a model form unit agreement that is acceptable to a significant majority of the numerous different players that can be expected to use it. It is unlikely that anyone will find the 1992 Model to be completely satisfactory in all respects, but the sentiment of the Task Force in this respect is summarized in the following excerpt from the memorandum under cover of which the Task Force submitted the penultimate draft of the model to the parties involved in the finalization thereof:

Something that the task force would request be kept in mind in reviewing ... the new draft of the agreement is that the basic objective of the model is to delineate the respective rights and obligations of prospective unit participants in a manner which:

(a) strikes a reasonable balance among the divergent needs and wants of five basic interest groups (i.e., large Working Interest Owners, small Working Interest Owners, the Crown, large industry Royalty Owners and small individual Royalty Owners), as well as among the divergent needs and wants of individual players within certain of those groups;

(b) strikes a reasonable balance between the desire for simplicity and the need to minimize uncertainty and the potential for conflict through comprehensive treatment of complex issues; and

(c) permits the use of the model in a relatively broad range of common unitization situations.

Achieving this objective is obviously a tall order, and it requires the proponents of the concept of a model form document to understand that the model is not intended to serve as a cure-all for every one of their own particular unitization concerns. If we are to achieve our objectives, the document must be a product of reasonable accommodation and compromise, as it simply cannot provide every prospective unit participant with everything that he, she or it may want. 
It is hoped that this thought will be kept in mind by persons reviewing and using the 1992 Model.

It should be noted that the 1992 Model will not be circulated for general use until a complete set of guide notes and a compatible model form unit operating agreement have been completed. It is presently anticipated that this package will be available in October or November 1992.

It should also be noted that neither the PJVA nor the Crown considers the 1992 Model to be a document that is "carved in stone." The Model is to be monitored on an ongoing basis by a joint PJVA/Crown review group, and modifications will be made from time to time as circumstances dictate. 


\section{APPENDIX}

UNIT AGREEMENT

[NAME OF UNIT]

\section{PJVA MODEL FORM}

VERSION NO. 1

JUNE 1, 1992 
TABLE OF CONTENTS

Page

ARTICLE I

INTERPRETATION

101.

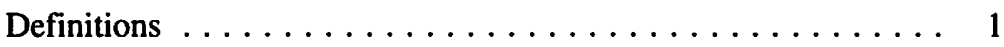

102.

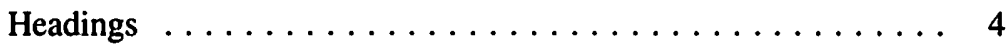

103.

Number and Gender $\ldots \ldots \ldots \ldots \ldots \ldots \ldots \ldots \ldots$

104.

105.

Time ....................... 4

Statutory References $\ldots \ldots \ldots \ldots \ldots \ldots \ldots \ldots \ldots$

ARTICLE II

EXHIBITS

201.

202.

203.

204.

205.

206.

207.

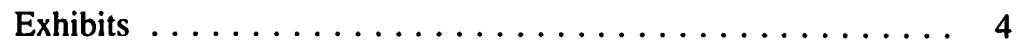

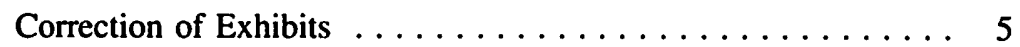

Effective Time of Exhibits ............... 5

Exhibits Deemed Correct $\ldots \ldots \ldots \ldots \ldots \ldots \ldots \ldots$

Identification of Exhibits $\ldots \ldots \ldots \ldots \ldots \ldots \ldots$

Preparation and Distribution of Exhibits ........... 6

Conflicts $\ldots \ldots \ldots \ldots \ldots \ldots \ldots \ldots \ldots \ldots$

301.

ARTICLE III

UNITIZATION AND EFFECT

302.

303.

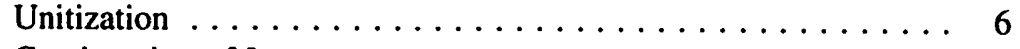

Continuation of Leases $\ldots \ldots \ldots \ldots \ldots \ldots \ldots \ldots \ldots \ldots \ldots$

304.

Extraneous Defaults ................... 7

305.

Amendment of Leases $\ldots \ldots \ldots \ldots \ldots \ldots \ldots \ldots \ldots$

306.

Ratification of Leases ................. 7

307.

308.

Effect of Unitization on Titles $\ldots \ldots \ldots \ldots \ldots \ldots \ldots .8$

Equipment and Facilities $\ldots \ldots \ldots \ldots \ldots \ldots \ldots \ldots$

Name .................... 8

ARTICLE IV

AUTHORITY TO WORKING INTEREST OWNERS

401.

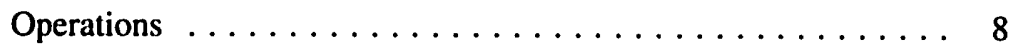

402.

403.

Delegation .................. 8

Vote of Working Interest Owners $\ldots \ldots \ldots \ldots \ldots \ldots .9$

ARTICLE V

INCLUSION AND QUALIFICATION OF TRACTS

501. Tracts Included as of Effective Date $\ldots \ldots \ldots \ldots \ldots$

502. Qualification of Tracts $\ldots \ldots \ldots \ldots \ldots \ldots \ldots \ldots \ldots$

[503. Revision of Exhibits $\ldots \ldots \ldots \ldots \ldots \ldots \ldots \ldots \ldots$ 10] 


\section{ARTICLE VI \\ TRACT PARTICIPATION}

601.

Tract Participation

\section{ARTICLE VII \\ ALLOCATION OF UNITIZED SUBSTANCES PRODUCED}

701.

Allocation among Tracts $\ldots \ldots \ldots \ldots \ldots \ldots \ldots \ldots$

702.

Allocation among Parties $\ldots \ldots \ldots \ldots \ldots \ldots \ldots \ldots \ldots$

703.

704.

705.

706.

Calculation of Royalty ................... 11

Satisfaction of Royalty Obligations $\ldots \ldots \ldots \ldots \ldots \ldots \ldots 11$

Disposition of Unitized Substances $\ldots \ldots \ldots \ldots \ldots \ldots \ldots 12$

Recovery of Outside Substances . . . . . . . . . . . 12

ARTICLE VIII

USE, LOSS AND RE-INJECTION OF UNITIZED SUBSTANCES

801.

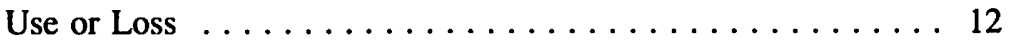

802.

Re-Injection

\section{ARTICLE IX \\ APPROVAL OF TITLES}

901.

902.

903.

904.

Titles Committee ...................... 13

Approval of Titles by Working Interest Owners $\ldots \ldots \ldots \ldots 13$

Warranty of Title $\ldots \ldots \ldots \ldots \ldots \ldots \ldots \ldots \ldots \ldots \ldots$

Title Failure Clarification ................. 14

1001.

\section{ARTICLE X \\ ENLARGEMENT}

1002.

1003.

1004.

1005.

1006.

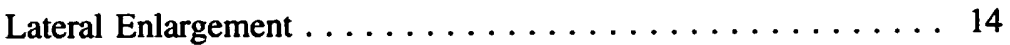

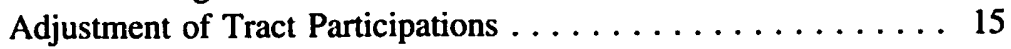

Effective Time of Enlargement $\ldots \ldots \ldots \ldots \ldots \ldots \ldots 15$

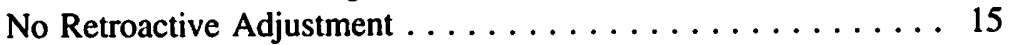

Title Matters . . . . . . . . . . . . . . . . . 15

Non-Application of Enlargement Provisions . . . . . . . 15

1101.

ARTICLE XI
TITLE DISPUTES

1102.

1103.

1104.

1105 .

1106.

1107.

1108.

1109.

Working Interest Title Disputes $\ldots \ldots \ldots \ldots \ldots \ldots \ldots$

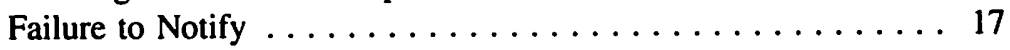

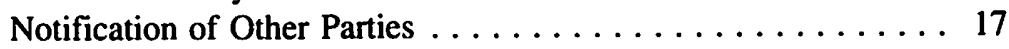

Interim Royalty Arrangements $\ldots \ldots \ldots \ldots \ldots \ldots \ldots$

Clarification of Obligations $\ldots \ldots \ldots \ldots \ldots \ldots \ldots \ldots$

Royalty Owner Recourse $\ldots \ldots \ldots \ldots \ldots \ldots \ldots \ldots \ldots$

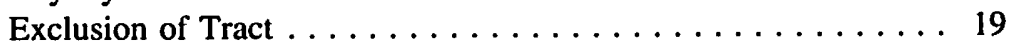

Existing Party Beneficiary . . . . . . . . . . . . . 19

Response to New Lease Offer . . . . . . . . . 20 


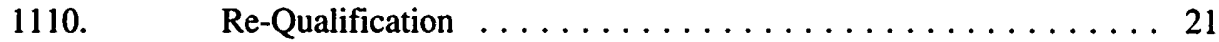

1111. Interim Working Interest Rights $\ldots \ldots \ldots \ldots \ldots \ldots \ldots 21$

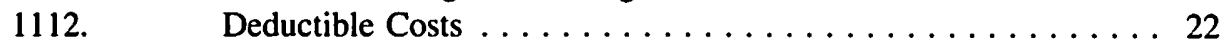

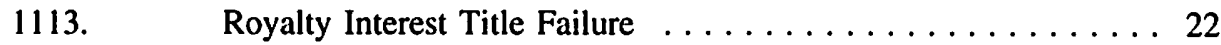

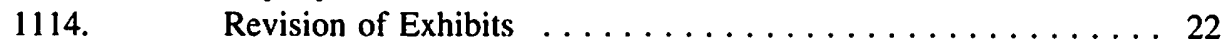

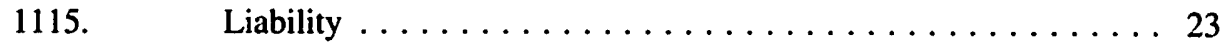

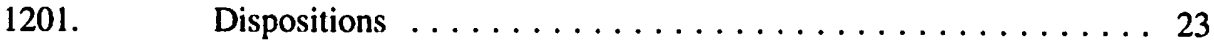

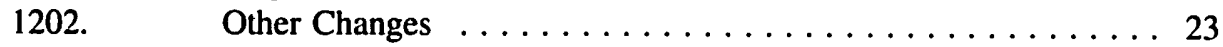

1301. Effective Date . . . . . . . . . . . . . . . . . 24

1302. Notice of Effective Date $\ldots \ldots \ldots \ldots \ldots \ldots \ldots \ldots 24$

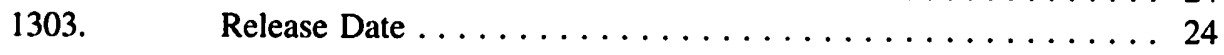

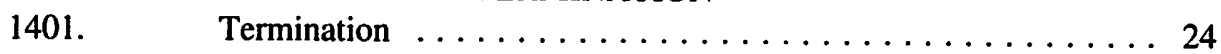

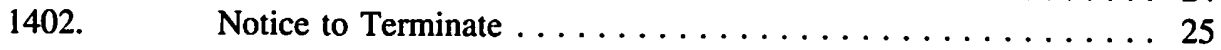

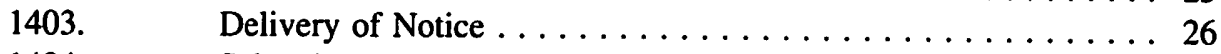

1404. Salvaging Equipment Upon Termination $\ldots \ldots \ldots \ldots \ldots \ldots 26$

1405. Notice to Royalty Owners $\ldots \ldots \ldots \ldots \ldots \ldots \ldots \ldots$

ARTICLE XV
MISCELLANEOUS
1501.
1502. Execution in Counterpart $\ldots \ldots \ldots \ldots \ldots \ldots \ldots \ldots \ldots \ldots \ldots \ldots \ldots \ldots \ldots$

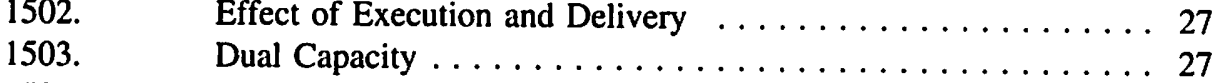

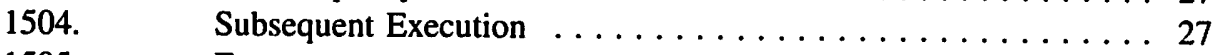

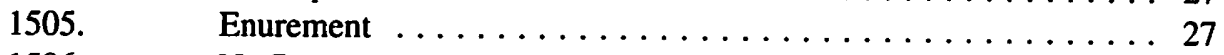

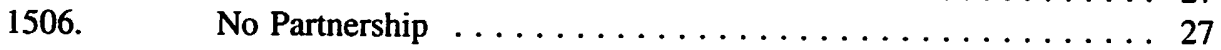

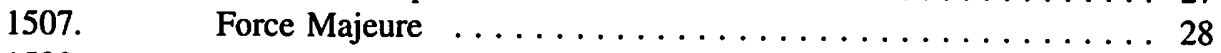

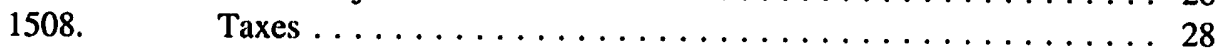

1509. Delinquent Payment Obligations $\ldots \ldots \ldots \ldots \ldots \ldots \ldots \ldots 28$

1510. Notices ........................ 29

1511. Time of the Essence . . . . . . . . . . . . 29

1512. Compliance with Laws and Regulations ............. 29

1513. Governing Law $\ldots \ldots \ldots \ldots \ldots \ldots \ldots \ldots \ldots \ldots \ldots \ldots$ 
PJVA Model Form Version No. 1

June 1, 1992

\section{UNIT AGREEMENT}

[NAME OF UNIT]

WHEREAS the Parties own Royalty Interests and Working Interests, or either of them, in the Unitized Substances;

AND WHEREAS the Parties desire that the Unitized Zone be developed, produced and operated as a unit;

NOW THEREFORE in consideration of the covenants herein contained the Parties agree as follows:

\section{ARTICLE I \\ INTERPRETATION}

101. Definitions

In this Agreement, including the premises and the exhibits hereto:

a. "Affiliate" means, with respect to any person, any other person which is affiliated with such person, and for the purposes hereof:

(i) two persons will be considered to be affiliated with one another if one of them controls the other, or if both of them are controlled by a common third person, and

(ii) one person will be considered to control another person if it has the power to direct or cause the direction of the management and policies of the other person, whether directly or indirectly, through one or more intermediaries or otherwise, and whether by virtue of the ownership of shares or other equity interests, the holding of voting rights or contractual rights, or otherwise;

b. "Crown" means Her Majesty the Queen in right of the Province of Alberta;

c. "Effective Date" means the time and date referred to in clause 1301;

d. "Lease" means an instrument granting a Working Interest of the kind described in paragraph 101(s)(i) in respect of any portion of the Unitized Zone; 
e. "Outside Substances" means:

(i) any substances which were initially obtained from any source other than the Unitized Zone, or any Unitized Substances which have been produced,

and with respect to which there is no royalty liability outstanding;

f. "Party" means a person who is bound by this Agreement;

g. "Petroleum Substances" means petroleum, natural gas and related hydrocarbons (other than coal) and any other substances, whether hydrocarbons or not, which are produced in association therewith, or any of them;

h. "Royalty Interest" means:

a Crown or other sovereign ownership interest, or a fee simple or similar freehold ownership estate, in respect of Petroleum Substances in or producible from the Formation, or

(ii) a right to a share of Petroleum Substances produced from the Formation, to a share of the proceeds from the sale of such Petroleum Substances, or to a payment based on the quantity or value of such Petroleum Substances,

but does not include a Working Interest, the interest of a purchaser of such Petroleum Substances after production, a mortgage, charge or other security interest, or any right of a government or governmental agency to a payment in respect of taxes or similar assessments;

i. "Royalty Owner" means a Party owning a Royalty Interest in or in respect of Unitized Substances;

j. "Tract" means a parcel of land described and given a Tract number in Exhibit "A", and shown outlined in Exhibit "B";

k. "Tract Participation" means the participation percentage assigned to a Tract pursuant to Article VI;

1. "Unit Area" means the lands described in Exhibit "A" and shown outlined on Exhibit "B";

m. "Unit Operating Agreement" means the agreement entitled "Unit Operating Agreement " entered into by the Working Interest Owners; 
n. "Unit Operations" means any operations or activities undertaken on behalf of the Working Interest Owners in connection with the development or exploitation of the Unitized Zone, the production or other handling of Unitized Substances or the installation, operation, maintenance or removal of equipment or facilities, insofar as such operations or activities have been authorized or provided for under this Agreement or the Unit Operating Agreement;

o. $\quad$ "Unit Operator" means the Working Interest Owner which is from time to time designated as Unit Operator under the Unit Operating Agreement;

p. "Unit Participation" means, with respect to each Working Interest Owner, the sum of all of its Tract Participation shares as set forth in Part I of Exhibit "A";

q. "Unitized Substances" means Petroleum Substances in or obtained from the Unitized Zone;

r. "Unitized Zone" means the Formation within the Unit Area;

s. "Working Interest" means an interest in:

a profit à prendre or similar interest entitling the owner thereof to produce and dispose of Petroleum Substances from the Formation, or

(ii) the production and disposition rights associated with a Crown or other sovereign ownership interest, or a fee simple or similar freehold ownership estate, in respect of Petroleum Substances in or producible from the Formation, if such rights are not subject to an interest of the kind described in paragraph (i) of this subclause,

but does not include a mortgage, charge or other security interest;

t. "Working Interest Owner" means a Party owning a Working Interest in or in respect of Unitized Substances; and

u. " Formation" means the occurring between the depths

of metres and metres on the Log of

situated in legal subdivision of section township range , west of the meridian, as identified in Exhibit "C". 
102.

Headings

The headings of the Articles and clauses of this Agreement have been inserted for convenience of reference only and shall not affect the construction or interpretation hereof.

103. Number and Gender

In this Agreement words importing the singular include the plural and vice versa, words importing gender include the masculine, feminine and neuter genders, and references to persons include individuals, corporations, partnerships, bodies politic and other entities, all as the context may require.

104.

Time

In this Agreement all times are Mountain Standard Time or Daylight Saving Time, whichever is then being used and observed in accordance with the Daylight Saving Time Act (Alberta).

105. Statutory References

In this Agreement references to the Mines and Minerals Act and other statutes of Alberta shall be construed as references to the relevant statute as amended from time to time, and shall include any statutory replacements of the whole or any part thereof, and all regulations and other subordinate legislation issued from time to time thereunder.

\section{ARTICLE II EXHIBITS}

201. Exhibits

The following exhibits are attached to and incorporated in this Agreement:

(a) Exhibit "A", Part I of which numbers and describes each Tract and, with respect to each Tract:

(i) sets forth its Tract Participation,

(ii) sets forth the names of the owners of the Working Interests therein, their respective percentage Working Interests therein, and their respective shares of the Tract Participation therefor,

(iii) sets forth the names of the owners of the Royalty Interests therein, and 
(iv) identifies the Lease relating thereto, if any,

and Part II of which lists all of the Working Interest Owners and sets forth their respective Unit Participations;

(b) Exhibit "B", which is a plate showing the Unit Area and identifying the Tracts;

(c) Exhibit "C", which is a reproduction of a portion of the log referred to in subclause 101(u); and

(d) Exhibit "D", which sets forth the procedure for dealing with failure to make adequate arrangements for the disposition of Unitized Substances upon production.

202.

\section{Correction of Exhibits}

If an error of a clerical nature occurs in an exhibit, the Unit Operator shall, forthwith upon discovering or being notified of the same, effect appropriate corrections to the exhibit. The provisions of this clause do not extend to any error occurring in the course of the compilation and evaluation of technical data for purposes of establishing the respective Tract Participations, it being agreed that the results of such evaluation process are conclusive and shall not be subject to challenge or dispute.

203.

\section{Effective Time of Exhibits}

Except as otherwise expressly provided in this Agreement:

(a) the exhibits attached to the original execution version of this Agreement shall [, unless subsequently revised pursuant to the provisions of clause 503,] be effective as of the Effective Date;

(b) any exhibit which is revised pursuant to the provisions of this Agreement shall be effective in its revised form as of the time specified by the provision requiring or authorizing such revision; and

(c) any exhibit which is corrected pursuant to clause 202 shall be effective in its corrected form as of 08:00 on the first day of the calendar month next following the date on which the Unit Operator first discovers or is notified of the error requiring correction; provided, however, that if the Unit Operator discovers or is notified of a clerical error in an exhibit within thirty (30) days of the date of issuance by the Unit Operator of the version of the exhibit containing the error, the corrected version of the exhibit shall be effective as of the date on which the version of the exhibit containing the error would otherwise have been effective, and the version of the exhibit containing the error shall be deemed conclusively never to have been effective. 
204.

Exhibits Deemed Correct

Subject to the proviso set forth in subclause 203(c), each exhibit, and each revised or corrected version thereof, shall for purposes of this Agreement be deemed conclusively to be correct and binding on the Parties from the time at which it becomes effective until the time at which a revised or corrected version thereof becomes effective.

205.

Identification of Exhibits

Revised and corrected versions of exhibits shall be numbered consecutively, shall indicate the date on which they become effective, and shall indicate whether they are revised or corrected versions of an exhibit, or both.

206.

\section{Preparation and Distribution of Exhibits}

Each time that an exhibit is to be revised or corrected pursuant to this Agreement the Unit Operator shall effect the required revisions or corrections in a timely and diligent manner and shall forthwith:

(a) provide the Crown with two copies of the revised or corrected version of the exhibit, and

(b) provide each of the Working Interest Owners with one copy of the revised or corrected version of the exhibit.

The Working Interest Owners shall provide their Royalty Owners, other than the Crown, with a copy of the revised or corrected version of the exhibit forthwith upon receipt of the same from the Unit Operator.

207.

Conflicts

In the event of any conflict between the provisions of the principal text of this Agreement and the provisions of Exhibit " $D$ " hereto, the provisions of the principal text hereof shall take precedence.

\section{ARTICLE III \\ UNITIZATION AND EFFECT}

301 .

Unitization

The interests of each Royalty Owner and each Working Interest Owner in and in respect of the Unitized Substances and the Unitized Zone are hereby unitized in accordance with the provisions of this Agreement. 
302.

\section{Continuation of Leases}

Until such time as the unitization provided for herein terminates pursuant to the provisions of clause 1401, such unitization shall continue in force and effect each Lease and other agreement or instrument relating to the Unitized Zone or Unitized Substances to the same extent as if a well had been drilled to, and was throughout the term of such unitization producing Petroleum Substances from, all of the Unitized Zone in each Tract and each spacing unit or other parcel forming part thereof; provided, however, that if under the terms of any Lease or other agreement or instrument relating to the Unitized Zone or Unitized Substances any Party would at any time be required to make any shut-in royalty or similar payment in the absence of actual production of Unitized Substances from the Unit Area, whether as an unconditional obligation or as a condition to continuing such Lease or other agreement or instrument in effect, such payment requirement shall continue to apply notwithstanding the deemed production provisions of this clause 302 .

303.

\section{Extraneous Defaults}

If any Lease should at any time during the term of the unitization provided for herein become terminable in whole or in part, whether automatically in accordance with its terms or at the option of the lessor thereunder, as a result of any default in obligations relating to any lands or zones other than the Unitized Zone, such Lease or terminable part thereof shall nonetheless continue in effect insofar as it relates to the Unitized Zone, as though it had been granted only in respect of the Unitized Zone in the Tract or Tracts to which it relates. The provisions of this clause 303 shall not apply with respect to any default in obligations relating in whole or in part to the Unitized Zone.

304.

Amendment of Leases

Subject to the provisions of clause 1512, in the event of any conflict between the provisions of this Agreement and the provisions of any Lease or other agreement or instrument relating to the Unitized Zone or Unitized Substances, the provisions of this Agreement shall take precedence, and each Lease and other agreement or instrument relating to the Unitized Zone or Unitized Substances is accordingly hereby amended to the extent necessary to make it conform with the provisions of this Agreement; provided, however, that except as specifically required to give effect to the provisions of this Agreement, the respective rights and obligations of the Parties under the various Leases and other agreements and instruments relating to the Unitized Zone or Unitized Substances shall not be either diminished or increased hereby.

305.

\section{Ratification of Leases}

Except for a Lease with respect to which a Royalty Owner is involved in a court action which has been commenced and is pending on the date on which such Royalty Owner executes and delivers a counterpart of this Agreement, each Royalty Owner hereby ratifies each Lease, as amended by this Agreement, to which it is a party, and hereby 
confirms that no notice of default has been given and remains outstanding with respect to any such Lease, and that each such Lease is in effect as of the date of such execution and delivery. The provisions of this clause 305 do not constitute a waiver, and shall not give rise to an estoppel, of any right to pursue the enforcement of any outstanding obligation under any such Lease.

306.

\section{Effect of Unitization on Titles}

Nothing in this Agreement or the Unit Operating Agreement shall be construed as effecting any transfer or exchange of any interest in the Leases, the Tracts or the Unitized Zone, or in the Unitized Substances before production thereof.

307.

\section{Equipment and Facilities}

All equipment and facilities used in connection with Unit Operations and heretofore or hereafter installed, affixed or constructed by any of the Working Interest Owners on or in any lands within the Unit Area are and shall remain the personal property of the Working Interest Owners, or such of them as may from time to time have an interest therein, and, except as otherwise provided in clause 1404, no interest in any such equipment and facilities shall vest in the Royalty Owners by virtue of the provisions of this Agreement.

308.

Name

The name of the unit hereby constituted is

\section{ARTICLE IV \\ AUTHORITY TO WORKING INTEREST OWNERS}

401. Operations

The Working Interest Owners are hereby granted the right to develop, produce and otherwise operate the Unitized Zone without regard to the boundary lines of the Tracts or the provisions of the Leases, in such manner and by such means and methods as the Working Interest Owners may consider appropriate. Without limiting the generality of the foregoing, the Working Interest Owners shall have the right to inject any substance or combination of substances into the Unitized Zone and to convert and use as injection wells any wells now existing or hereafter drilled into the Unitized Zone.

402.

Delegation

The Working Interest Owners may delegate to the Unit Operator any of the rights and powers herein or otherwise granted to them. 
403. Vote of Working Interest Owners

Any matter to be determined under this Agreement by the Working Interest Owners shall be determined by vote of the parties to the Unit Operating Agreement as prescribed therein.

\section{ARTICLE V \\ INCLUSION AND QUALIFICATION OF TRACTS}

501. Tracts Included as of Effective Date

The Tracts to be included in the Unit Area as of the Effective Date are those Tracts which qualify for such inclusion pursuant to clause 502:

(a) before the Effective Date; [or

(b) on or within __ days following the Effective Date.]

502. Qualification of Tracts

A Tract qualifies for inclusion in the Unit Area when [its title has been approved by the Working Interest Owners pursuant to clause 902 and]:

(a) the owners of one hundred (100\%) percent of the Working Interests therein have become Parties and parties to the Unit Operating Agreement and the owners of one hundred $(100 \%)$ percent of the Royalty Interests therein have become Parties; or

(b) the owners of one hundred (100\%) percent of the Working Interests therein have become Parties and parties to the Unit Operating Agreement and the owners of less than one hundred $(100 \%)$ percent of the Royalty Interests therein have become Parties, and the owners of the Working Interests therein provide the other Working Interest Owners with an indemnification in form and substance satisfactory to them, protecting them against any loss or damages that may be suffered by them in respect of claims and demands that, because of the inclusion of the Tract in the Unit Area, may be made by those owners of Royalty Interests in the Tract who have not become Parties; or

(c) the owners of Working Interests therein have satisfied such other requirements as the other Working Interest Owners may consider appropriate as a basis for qualifying such Tract, where the Tract cannot be qualified pursuant to either subclause (a) or (b) of this clause 502 . 
$[503$.

Revision of Exhibits

If any of the Tracts originally set forth in Exhibit "A" do not qualify for inclusion in the Unit Area by the date days following the Effective Date, the Unit Operator shall revise Exhibits "A" and "B" so as to include therein only those Tracts which have qualified for inclusion in the Unit Area by such date. If Exhibits "A" and "B" are required to be so revised:

(a) the Tract Participations ascribed to the qualifying Tracts in the revised version of Exhibit " $\mathrm{A}$ " shall be adjusted such that their summation is one hundred $(100 \%)$ percent and they remain proportionately the same, relative to one another, as they were in the original version of Exhibit "A"; and

(b) the revised versions of such Exhibits shall be effective as of the Effective Date.]

\section{ARTICLE VI \\ TRACT PARTICIPATION}

601.

Tract Participation

Each Tract has the Tract Participation assigned to it in Exhibit "A".

\section{ARTICLE VII \\ ALLOCATION OF UNITIZED SUBSTANCES PRODUCED}

701. Allocation among Tracts

Subject to the provisions of clauses 706, 801 and 802, Unitized Substances shall when produced be allocated among the Tracts in accordance with their respective Tract Participations, and the amount of Unitized Substances so allocated to each Tract, and only that amount, regardless of whether it be more or less than the amount of actual production of Unitized Substances from the well or wells, if any, on the Tract, shall be deemed conclusively to have been produced from the Unitized Zone in the Tract.

702.

Allocation among Parties

The Unitized Substances allocated to a Tract shall be further allocated among the Working Interest Owners thereof in accordance with their respective percentage Working Interests in the Tract as set forth in Exhibit "A", and in the event that any portion of any Unitized Substances so allocated to a Working Interest Owner is deliverable in kind to, or is otherwise subject to proprietary rights in favour of, an owner of a Royalty Interest in respect of such Unitized Substances, such Working Interest Owner shall ensure that 
such royalty delivery or other proprietary rights are given effect to, subject to the provisions of Article XI.

703.

\section{Calculation of Royalty}

The amount of any royalty payable or deliverable to a Royalty Owner in respect of Unitized Substances under any Lease or other agreement or instrument applicable to a Tract shall be calculated (at the applicable rate under such Lease or other agreement or instrument, and having regard to any minimum royalty obligations thereunder) on the basis only of the amount of Unitized Substances deemed to have been produced from such Tract pursuant to the provisions of clause 701, as if such amount of Unitized Substances had been produced from a single well located on such Tract, and the payment or delivery, as the case may be, of royalty so calculated shall satisfy the obligation to pay or deliver royalty in respect of Unitized Substances under any such Lease or other agreement or instrument. Without limiting the generality of the provisions of clause 1512 , in the event of any conflict between the provisions of this clause 703 and the manner in which Crown royalty rates are determined, the latter shall take precedence.

704.

\section{Satisfaction of Royalty Obligations}

The Working Interest Owners of each Tract shall be responsible for accounting to the owners of Royalty Interests in respect of such Tract for any royalty payable or deliverable to such owners in respect of Unitized Substances, and, except as otherwise expressly provided in subclause 1101 (c) and clause 1104, nothing in this Agreement shall be construed as giving rise to any right entitling an owner of a Royalty Interest in respect of a Tract:

(a) to look to any Working Interest Owners other than the Working Interest Owners of such Tract for the satisfaction of royalty obligations in respect of such Tract; or

(b) if the Royalty Interest relates to less than $100 \%$ of the Working Interests in the Tract, to look to any Working Interest Owners other than the owners of the particular Working Interests encumbered by the Royalty Interest for the satisfaction of obligations in respect thereof;

provided, however, that in the event that the beneficial Working Interest Owners of a Tract are not the same persons as the lessee under a Lease relating to the Tract, the provisions of this clause 704 shall not be construed as relieving such lessee of any obligation to account for royalty payable or deliverable to the lessor under such Lease if the Working Interest Owners fail to comply with their obligations in that respect. 
705.

Disposition of Unitized Substances

The share of Unitized Substances allocated to each Working Interest Owner pursuant to the provisions of clauses 701 and 702 shall be a several share, and the right to possession of, and the responsibility for, such share shall vest in each Working Interest Owner upon production. Each Working Interest Owner shall, not less than __ days prior to the commencement of production of Unitized Substances pursuant hereto, and thereafter not less than days prior to any change in disposition arrangements, provide the Unit Operator with a written notice setting forth such information with respect to such Working Interest Owner's arrangements for the disposition of its allocated share of Unitized Substances (including any portion thereof which is to be taken in kind by a Royalty Owner) as the Unit Operator may reasonably require in order to facilitate such arrangements. Such notice shall remain in effect and shall bind such Working Interest Owner until the later of the date specified in any written replacement notice in respect thereof and the date days following the date on which such replacement notice is delivered to the Unit Operator. In the event that a Working Interest Owner fails to provide such a notice, or in the event that any of the disposition arrangements specified in such a notice are inadequately provided for or are otherwise unworkable or impracticable, or at any time cease to be adequately provided for or otherwise become unworkable or impracticable, the Unit Operator shall forthwith so notify such Working Interest Owner, and the provisions of Exhibit " $D$ " shall apply. The Working Interest Owners may from time to time change the time for giving a notice pursuant to this clause 705 , or specify the required form or contents of such a notice, in which event the Unit Operator shall notify the Crown, and each Working Interest Owner shall notify its Royalty Owners, other than the Crown, of such change in notice requirements not less than thirty (30) days prior to the date upon which such change becomes effective.

706.

Recovery of Outside Substances

If any Outside Substances are injected into the Unitized Zone, the first like substances subsequently produced from the Unitized Zone for sale or for use other than for Unit Operations shall be deemed conclusively to be such Outside Substances until a quantity equal to the quantity of the Outside Substances injected into the Unitized Zone is recovered. Unitized Substances which are so deemed to be Outside Substances shall not be allocable to the Tracts, and accordingly no royalty shall be payable or deliverable in respect of such substances as Unitized Substances.

\section{ARTICLE VIII \\ USE, LOSS AND RE-INJECTION OF UNITIZED SUBSTANCES}

801. Use or Loss

The Working Interest Owners shall be entitled to use as much of the Unitized Substances, other than crude oil, as may reasonably be required for Unit Operations. No 
Unitized Substances consumed through such use, and no Unitized Substances lost in the conduct of Unit Operations, shall be allocable to the Tracts, and accordingly no royalty shall be payable or deliverable in respect thereof. The provisions of this clause 801 shall not be construed as relieving the Unit Operator or any other Working Interest Owner from any liability which it would have for any loss of Unitized Substances resulting from its negligence or wilful misconduct.

802.

Re-Injection

The Working Interest Owners are hereby granted the right to re-inject Unitized Substances into the Unitized Zone for any purpose related to Unit Operations. No Unitized Substances so re-injected shall be allocable to the Tracts until such time as they are ultimately recovered for sale or for use other than for Unit Operations, and accordingly no royalty shall be payable or deliverable in respect thereof until such time.

\section{ARTICLE IX APPROVAL OF TITLES}

901. Titles Committee

The Working Interest Owners shall appoint a titles committee to investigate the ownership of the Working Interests and Royalty Interests in all Tracts, and each Working Interest Owner shall be entitled to be represented thereon. Each Working Interest Owner shall submit to the titles committee such title data and information as the titles committee may reasonably require from time to time for the purposes of such investigation. The titles committee shall report the result of its investigation to the Working Interest Owners and shall make recommendations with respect to approval of titles to Tracts, identifying those Tracts the titles to which it unanimously recommends for approval.

902.

Approval of Titles by Working Interest Owners

The Working Interest Owners may approve or decline to approve the titles for each Tract on such basis as they consider appropriate in the circumstances. A decision of the Working Interest Owners to approve a title notwithstanding knowledge of subsisting or prospective deficiencies therein shall not be construed as an acceptance of or acquiescence in any such deficiency, and shall not relieve any Party of any liability which it might have under the provisions of clause 903 , or of any obligations assumed by it as a Working Interest Owner under any other provision of this Agreement or the Unit Operating Agreement.

903.

Warranty of Title

Each of the Parties having a Working Interest ascribed to it in Exhibit "A": 
(a) represents and warrants that it is the owner of the Working Interests ascribed to it in Exhibit "A", and that it has full right, power and authority to commit the said Working Interests to unitization in accordance with the provisions of this Agreement, and to thereby bind the same; and

(b) shall be liable to each of the other Parties for, and shall indemnify and save harmless each of the other Parties against and from, any liability, loss, costs, claims or damages of any nature sustained by such Party as a result of:

(i) any breach or failure of such representation and warranty, whether in whole or in part, or

(ii) any failure of, or defect in, the title to any of the Working Interests ascribed to it in Exhibit "A", no matter when occurring or arising.

904. Title Failure Clarification

Without in any manner limiting the generality of the meaning of failure of title, the cancellation, surrender or other termination of a Lease for any reason whatsoever shall for the purposes of this Agreement be regarded as a failure of title.

\section{ARTICLE X \\ ENLARGEMENT}

1001.

Lateral Enlargement

If at any time [subsequent to the expiration of days] following the Effective Date the Working Interest Owners wish to enlarge the Unit Area to include any lands in the vicinity of the Unit Area appearing to be potentially productive of Petroleum Substances from the Formation, the Working Interest Owners may approve the enlargement of the Unit Area to include such lands on such terms and conditions as the Working Interest Owners may consider appropriate, and, if such lands qualify for inclusion in the Unit Area pursuant to clause 502, the Unit Area shall be enlarged to include such lands. Notwithstanding that any owner of a Working Interest or a Royalty Interest in such lands is already a Party, such owner shall not, for the purposes of the qualification of such lands pursuant to clause 502 , be considered to have executed and delivered this Agreement until it executes and delivers to the Unit Operator an additional counterpart of this Agreement incorporating exhibits which reflect the proposed enlargement and which are stated to be effective as of the effective date of such enlargement. 
1002.

\section{Adjustment of Tract Participations}

The Tract Participation to be assigned to each Tract added to the Unit Area in accordance with the provisions of this Article $\mathrm{X}$ shall be determined by the Working Interest Owners in conjunction with their approval of the enlargement giving rise to such addition, and upon such enlargement becoming effective the Tract Participations shall be adjusted such that:

(a) the total of all Tract Participations remains one hundred (100\%) percent; and

(b) the Tract Participations of all Tracts other than those being added remain proportionately the same, relative to one another, as they were immediately prior to the enlargement.

1003.

Effective Time of Enlargement

Each time that an enlargement is effected pursuant to the provisions of this Article X, the Unit Operator shall revise Exhibits "A" and "B" to reflect such enlargement, and the enlargement and the revised versions of such Exhibits shall become effective as of 08:00 on the first day of the calendar month following the date on which the lands to be included in the enlargement have qualified for inclusion pursuant to clause 502 .

1004.

No Retroactive Adjustment

Without limiting the generality of the provisions of clauses 203 and 204, no enlargement effected pursuant to the provisions of this Article $X$ shall at any time give rise to any retroactive adjustment of the allocation of Unitized Substances.

1005.

Title Matters

The provisions of Article IX shall apply, mutatis mutandis, with respect to any lands to be added to the Unit Area pursuant to the provisions of this Article X, and for the purposes thereof the term "Working Interest Owners" shall be construed as including the owners of the Working Interests in the lands proposed to be added to the Unit Area under the relevant enlargement proposal.

1006.

Non-Application of Enlargement Provisions

The provisions of this Article $\mathrm{X}$ shall not apply during any period in which all of the Working Interests in all of the Tracts are owned by a single Working Interest Owner, or by a group of Working Interest Owners all of which are Affiliates of one another, unless at least one of the owners of the Working Interest in the lands added to the Unit Area is different from, and is not an Affiliate of, the Working Interest Owners. 


\section{ARTICLE XI \\ TITLE DISPUTES}

1101.

Working Interest Title Disputes

If the title of a Party to a Working Interest ascribed to it in Exhibit "A" is disputed at any time, both that Party and any other Party which is a party to such dispute shall be obligated to provide the Unit Operator with notice of such dispute forthwith upon initiating or being advised of the same. Upon receipt of any such notice, or upon being directed to do so by the Working Interest Owners in the event that no such notice is given, the Unit Operator shall, and is hereby expressly authorized to, take possession of all Unitized Substances from time to time allocable to the owner of the disputed Working Interest pursuant to the provisions of clauses 701 and 702, sell such Unitized Substances on such reasonable terms as may be available to it in the circumstances, and, after deduction of such amounts as are deductible pursuant to the provisions of clause 1112, deposit the remaining proceeds from the sale thereof in an interest bearing trust account until:

(a) the Party whose Working Interest title is in dispute furnishes security, in form and substance satisfactory to the Working Interest Owners, for its obligation to account to the rightful owner of the disputed Working Interest should the title of such Party fail in whole or in part, whereupon the Unit Operator shall cease withholding the affected share of Unitized Substances, and shall release any sales proceeds deposited in trust, together with any interest accrued thereon, to such Party; or

(b) all of the parties to the dispute provide the Unit Operator with a joint written notice directing the Unit Operator to continue to treat the Party whose Working Interest is in dispute as the rightful owner of the disputed Working Interest pending final resolution of the dispute, and agreeing to indemnify and save harmless the Unit Operator and all of the other Working Interest Owners against and from any liability, loss, costs, claims or damages arising out of the Unit Operator's compliance with such direction, whereupon the Unit Operator shall cease withholding the affected share of Unitized Substances, and shall release any sales proceeds deposited in trust, together with any interest accrued thereon, to the Party whose Working Interest is in dispute; or

(c) the title to the disputed Working Interest is established by a final judgement of a court of competent jurisdiction, or otherwise to the satisfaction of the Working Interest Owners, whereupon the Unit Operator shall cease withholding the affected share of Unitized Substances, and shall release any sales proceeds deposited in trust, together with any interest accrued thereon, to the person rightfully entitled thereto. 
In the performance of its obligations under this clause 1101 the Unit Operator shall endeavour where practicable to honour existing marketing arrangements of which it is aware, and shall not be obligated to take any steps which would adversely affect any arrangements for the marketing of its own Petroleum Substances. In the event that the Unit Operator is unable to reasonably effect suitable marketing arrangements for any Unitized Substances withheld by it pursuant to the provisions of this clause 1101, the provisions of Exhibit "D" shall apply.

1102.

Failure to Notify

Any Party which is a party to a Working Interest title dispute and fails to give the Unit Operator notice of such dispute forthwith upon initiating or being advised of the same shall be liable for any liability, loss, costs, claims or damages suffered or incurred by the Unit Operator or any other Party as a result of such failure to notify in a timely manner.

1103. Notification of Other Parties

Forthwith upon becoming aware of any situation in which it is required to withhold Unitized Substances pursuant to the provisions of clause 1101, the Unit Operator shall provide notice thereof to all Working Interest Owners, and to all Royalty Owners which it is aware hold Royalty Interests relating to the particular disputed Working Interest.

1104.

Interim Royalty Arrangements

The Unit Operator shall not in its capacity as such be obligated to account to any Royalty Owner for any royalty payable or deliverable to such Royalty Owner in respect of any Unitized Substances withheld by the Unit Operator pursuant to the provisions of clause 1101, unless:

(a) the Unit Operator is provided with a written notice from the applicable Royalty Owner, setting forth in reasonable detail the terms and conditions of such Royalty Owner's royalty rights in respect of the Unitized Substances being withheld, directing the Unit Operator to give effect to such royalty rights, and agreeing to indemnify and save harmless the Unit Operator and all of the other Working Interest Owners against and from any liability, loss, costs, claims or damages arising out of the Unit Operator's compliance with such direction, in which event the Unit Operator shall, if it is satisfied, acting reasonably, with the ability of the Royalty Owner to fulfil its indemnification obligations, comply with the direction of such notice to the extent that it is practicable so to do; or

(b) the Unit Operator is provided with a joint written notice from all of the parties to the Working Interest dispute, setting forth in reasonable detail the terms and conditions of such Royalty Owner's royalty rights in respect of the Unitized 
Substances being withheld, directing the Unit Operator to give effect to such royalty rights, and agreeing to indemnify and save harmless the Unit Operator and all of the other Working Interest Owners against and from any liability, loss, costs, claims or damages arising out of the Unit Operator's compliance with such direction, in which event the Unit Operator shall comply with the direction of such notice to the extent that it is practicable so to do; or

(c) the Unit Operator is served with an order of a court of competent jurisdiction directing the Unit Operator to take any particular steps with respect to any royalty rights in respect of the Unitized Substances being withheld, in which event the Unit Operator shall comply with the direction of such order to the extent required by law.

1105.

\section{Clarification of Obligations}

In clarification of the obligations of the Unit Operator with respect to notices and orders with which it is required to comply pursuant to the provisions of clause 1104:

(a) the Unit Operator shall not at any time be obligated to satisfy any royalty payment obligation out of any funds other than the sales proceeds paid or payable into trust in respect of the Unitized Substances withheld;

(b) if any royalty rights to which the Unit Operator is required to give effect pursuant to the provisions of clause 1104 involve the delivery of any Unitized Substances in kind:

(i) the obligation of the Unit Operator to deliver such Unitized Substances in kind in compliance with the relevant notice or order shall take precedence over its obligation to withhold and sell such Unitized Substances pursuant to the provisions of clause 1101 , and

(ii) the Unit Operator shall be entitled to recover from the relevant Royalty Owner all costs which are properly chargeable to such Royalty Owner in respect of such delivery in kind under the terms of the relevant royalty rights; and

(c) any amounts required to be paid into or released from trust in accordance with the provisions of clause 1101 shall be net of any payments made by the Unit Operator in compliance with any notice or order with which the Unit Operator is required to comply pursuant to the provisions of clause 1104 .

1106. Royalty Owner Recourse

The provisions of clauses 1101 and 1104 shall not be construed as restricting in any manner any rights of recourse which a Royalty Owner may have against the Party 
whose Working Interest title is in dispute, or any other person having royalty obligations in respect of the disputed Working Interest, for any default in royalty obligations owing to such Royalty Owner, unless such Royalty Owner is itself disputing the Working Interest title in dispute, or unless the Working Interest title has been put in dispute by virtue of a dispute with respect to such Royalty Owner's title to a Royalty Interest ascribed to it in Exhibit " $\mathrm{A}$ " hereto. If a Royalty Owner is itself disputing the Working Interest title in dispute, or if the Working Interest title has been put in dispute by virtue of a dispute with respect to a Royalty Owner's title to a Royalty Interest ascribed to in Exhibit "A" hereto, such Royalty Owner shall not be entitled to terminate or seek the termination of any Lease or other agreement or instrument on the basis of the nonpayment or non-delivery of any royalty withheld in accordance with the provisions of clauses 1101 and 1104; provided, however, that:

(a) the provisions of clauses 1101 and 1104 shall not otherwise be construed as restricting in any manner any rights of recourse which such Royalty Owner may have against the Party whose Working Interest title is in dispute, or any other person having royalty obligations in respect of the disputed Working Interest, for any default in royalty obligations owing to such Royalty Owner, including, without limitation, any right which such Royalty Owner may have to sue such Party or other person for restitution or damages, and, subject to the provisions of clause 303 , any right which such Royalty Owner may have to terminate or seek the termination of such Lease or other agreement or instrument on the basis of any matter other than the non-payment or non-delivery of royalty withheld in accordance with the provisions of clauses 1101 and 1104; and

(b) the termination right limitations contemplated by this clause 1106 shall not apply with respect to a failure of the Unit Operator to comply in any material respect with any notice or order with which the Unit Operator is required to comply pursuant to the provisions of clause 1104.

If the title of a Party to a Working Interest ascribed to it in Exhibit " $\mathrm{A}$ " fails, and if no other Party then owns or is otherwise entitled to the benefit of the Working Interest in respect of which title has failed, and if the Tract to which such Working Interest relates does not re-qualify for inclusion in the Unit Area in the time and manner provided for in clause 1110 , such Tract shall be deemed conclusively to have been excluded from the Unit Area and to have ceased to have a Tract Participation as of 08:00 on the first day of the calendar month in which the failure of title is confirmed.

\section{Existing Party Beneficiary}

If the title of a Party to a Working Interest ascribed to it in Exhibit " $\mathrm{A}$ " fails, and if any other Party then owns or is otherwise entitled to the benefit of the Working Interest in respect of which title has failed, that Party shall, as of 08:00 on the first day of the 
calendar month in which the failure of title is confirmed, be bound by this Agreement and the Unit Operating Agreement as a Working Interest Owner with respect to such Working Interest; provided, however, that:

(a) if any such failure of title is the result of the cancellation, surrender or other termination of a Crown Lease, or of a portion of a Crown Lease, the Crown shall not be bound as a Working Interest Owner with respect to the Working Interest in respect of which title has failed, but shall be obligated to provide, within thirty (30) days of the day on which such failure of title is confirmed, a bona fide written offer to issue to the Unit Operator, on behalf of the Working Interest Owners as a whole, for a consideration not to exceed the amount of any outstanding royalty liability relating to Unitized Substances allocated to the subject Tract prior to 08:00 on the first day of the calendar month in which such failure of title is confirmed, a new Lease in respect of the

Formation in such Tract, covering the same Unitized Substances, and having substantially the same terms (other than as to the primary term thereof, which shall be the minimum primary term then permitted by the Mines and Minerals $A c t$ ) as the Lease, or portion of a Lease, which has terminated; and

(b) if any such failure of title is the result of the cancellation, surrender or other termination of a freehold Lease, or of a portion of a freehold Lease, the lessor thereunder shall not be bound as a Working Interest Owner with respect to the Working Interest in respect of which title has failed if within thirty (30) days of the day on which such failure of title is confirmed such lessor makes a bona fide written offer to grant to the Unit Operator, on behalf of the Working Interest Owners as a whole, for a consideration not to exceed the amount of any outstanding royalty and freehold mineral tax liability relating to Unitized Substances allocated to the subject Tract prior to 08:00 on the first day of the calendar month in which such failure of title is confirmed, a new lease in respect of the Formation in such Tract, covering the same Unitized Substances, and having substantially the same terms (other than as to the primary term thereof, which shall be a nominal primary term of ninety (90) days), as the Lease, or portion of a Lease, which has terminated.

1109. Response to New Lease Offer

If a new Lease offered pursuant to the provisions of clause 1108 is not accepted by the Working Interest Owners within sixty (60) days of the date the offer is received by the Unit Operator, the provisions of clause 1107 shall apply as though no other Party owned or was otherwise entitled to the benefit of the Working Interest in respect of which title had failed. If a new Lease offered pursuant to the provisions of clause 1108 is accepted within sixty (60) days of the date the offer is received by the Unit Operator:

(a) the new Lease shall be deemed to have been effective as and from the first day following the day on which the failure of title was confirmed; 
(b) the ownership of the Working Interest granted by the new Lease shall vest in the Working Interest Owners as tenants-in-common, each as to an undivided interest equal to the ratio of its Unit Participation to the sum of all Tract Participations, with both components of such ratio to be determined:

(i) as of 08:00 on the first day of the calendar month in which the failure of title was confirmed, and

(ii) without taking into account the Tract Participation of the Tract in respect of which the new Lease has been granted; and

(c) notwithstanding the effective date of the new Lease, and without limiting the generality of the provisions of clause 1114, the revision of Exhibit " $\mathrm{A}$ " to reflect the ownership of the Working Interest granted by the new Lease shall be effective as of 08:00 on the first day of the calendar month in which the failure of title was confirmed.

1110. Re-Qualification

If the title of a Party to a Working Interest ascribed to it in Exhibit "A" fails, and:

(a) if no other Party then owns or is otherwise entitled to the benefit of the Working Interest in respect of which title has failed, or

(b) if a new Lease offered pursuant to the provisions of clause 1108 is not accepted within the sixty (60) day acceptance period provided therefor,

but by the last day of the calendar month next following the calendar month in which the failure of title is confirmed the Tract to which the subject Working Interest relates re-qualifies for inclusion in the Unit Area on the basis of the criteria set forth in clause 502, then such Tract shall continue to be included in the Unit Area, and the provisions of clause 1114 shall apply with respect to any changes in the ownership of the Working Interests and Royalty Interests in such Tract.

1111. Interim Working Interest Rights

If the title of a Party to a Working Interest ascribed to it in Exhibit "A" fails, then until such time as a conclusive determination has been made with respect to whether the Tract to which such Working Interest relates is to be excluded from the Unit Area pursuant to the provisions of clause 1107:

(a) the Unit Operator shall, and is hereby expressly authorized to, take possession of all Unitized Substances allocated to such Tract pursuant to clause 701, sell such Unitized Substances on such reasonable terms as may be available to it in 
the circumstances, and, after deduction of such amounts as are deductible pursuant to the provisions of clause 1112 , deposit the remaining proceeds from the sale of such Unitized Substances in an interest bearing trust account for the benefit of the person or persons rightfully entitled thereto; and

(b) the provisions of the last two sentences of clause 1101, and the provisions of clauses 1103 through 1106 , shall apply, mutatis mutandis, during any period in which the Unit Operator is so withholding such Unitized Substances.

1112.

\section{Deductible Costs}

At any time at which the Unit Operator is taking possession of and selling any Unitized Substances pursuant to the provisions of either clause 1101 or clause 1111, it shall be entitled to deduct from the proceeds from the sale of such Unitized Substances, or to withdraw from any such proceeds deposited in trust, without duplication:

(a) the amount of all costs reasonably incurred by it in connection with the post-production handling and sale of such Unitized Substances, and

(b) the amount of all capital and non-capital Unit Operations costs which are chargeable to the Working Interest the title to which is in dispute;

provided, however, that if the Unit Operator has become obligated to give effect to any Royalty Interest rights pursuant to the provisions of clause 1104, it shall not be entitled to deduct or withdraw from any Royalty Interest share of such proceeds the amount of any such costs which are not properly chargeable to such Royalty Interest.

\section{Royalty Interest Title Failure}

If the title of a Party to a Royalty Interest ascribed to it in Exhibit "A" fails, and if any other Party then owns or is otherwise entitled to the benefit of the Royalty Interest in respect of which title has failed, that Party shall, as of 08:00 on the first day of the calendar month in which the failure of title is confirmed, be bound by this Agreement as a Royalty Owner with respect to such Royalty Interest.

\section{Revision of Exhibits}

Forthwith upon becoming aware of any changes required to be made to Exhibits "A" and "B" as the result of the failure of any Working Interest or Royalty Interest title, the Unit Operator shall revise such Exhibits to reflect such changes, and the revised versions of such Exhibits shall be effective as of 08:00 on the first day of the calendar month in which the failure of title is confirmed. In instances in which a Tract is excluded from the Unit Area pursuant to clause 1107, the Tract Participations of the remaining Tracts shall be adjusted such that their summation is one hundred $(100 \%)$ 
percent and they remain proportionately the same, relative to one another, as they were prior to such exclusion.

1115. Liability

None of the provisions of this Article XI shall be construed as relieving any Party of any liability which it might have under clause 903.

\section{ARTICLE XII \\ CHANGES IN INTERESTS}

1201.

Dispositions

In this Article XII the term "disposition" means any disposition of a Working Interest or a Royalty Interest, or any interest therein, whether legal or equitable, by way of sale, assignment, transfer, lease, sublease, conveyance, gift, change of possession or other transaction, and includes, without limitation, any realization upon any mortgage, charge or other security interest, but shall be deemed conclusively not to include the grant or other creation of any such security interest. A disposition of an interest in a Tract by a Party shall cover the whole of or an undivided interest in the whole of such Party's interest in the Tract, and no disposition shall be binding on the Unit Operator or the other Parties which are not parties to such disposition until:

(a) at least one of the parties to such disposition has given the Unit Operator written notice of such disposition, together with a copy of a document evidencing such disposition; and

(b) any acquiring parties which are not Parties have executed and delivered to the Unit Operator a counterpart of this Agreement and, in the event that the disposition is a disposition of a Working Interest, any acquiring parties which are not parties to the Unit Operating Agreement have executed and delivered to the Unit Operator a counterpart of the Unit Operating Agreement.

Upon being provided with all of such items in respect of a disposition the Unit Operator shall revise Exhibit " $A$ " to reflect such disposition, and the revised version of Exhibit "A" shall be effective as of 08:00 on the first day of the calendar month next following the calendar month in which such items are received by the Unit Operator.

1202.

\section{Other Changes}

If a Party changes its name or undergoes any other change affecting the information contained in Exhibit "A", other than by way of a disposition, such Party shall provide the Unit Operator with written notice of such change, together with a copy of a document evidencing the same. The Unit Operator shall thereupon revise Exhibit "A" to 
reflect such change, and the revised version of Exhibit " $A$ " shall be effective as of 08:00 on the first day of the calendar month next following the calendar month in which such items are received by the Unit Operator.

\section{ARTICLE XIII \\ EFFECTIVE DATE}

1301.

Effective Date

The unitization provided for herein shall become effective at 08:00 on the first day of the first calendar month following the date of the qualification under clause 502 of Tracts having a combined Tract Participation of total Tract Participations as originally set forth in Exhibit "A". percent [or more] of the

1302.

Notice of Effective Date

As soon as practicable after the Effective Date, the Unit Operator shall notify all Working Interest Owners and the Crown of the Effective Date [, and of the Tracts which were included in the Unit Area as of the Effective Date pursuant to clause 501,] and the Working Interest Owners shall advise their Royalty Owners, other than the Crown, of the Effective Date.

1303.

Release Date

This Agreement shall cease to bind the Parties if the unitization provided for herein has not become effective on or before the lst day of 19

\section{ARTICLE XIV \\ TERMINATION}

1401. Termination

The unitization provided for herein shall terminate upon the occurrence of the earliest of:

(a) its termination by the Working Interest Owners by vote taken under the Unit Operating Agreement,

(b) the expiration of a period of ninety (90) days following the time at which all wells used for the production of Unitized Substances have been abandoned, plugged or disposed of, and

(c) its termination in accordance with the provisions of clause 1402 , 
and the Parties shall thereupon cease to be bound by the provisions of this Agreement (other than the provisions of clauses 1404 and 1405), and shall thereafter be governed by the terms and provisions of their respective surviving Leases and other agreements and instruments relating to the Unitized Zone or Unitized Substances; provided, however, that the provisions of this clause 1401 shall not be construed as relieving any person from any obligation or liability accruing on its part under this Agreement prior to the termination of the unitization provided for herein.

1402.

\section{Notice to Terminate}

If Unit Operations are not commenced within of the Effective Date, or if Unit Operations are at any time after their commencement interrupted or suspended for any period in excess of , any Party may give the Unit Operator written notice of its desire to terminate the unitization provided for herein. If upon the expiration of a period of ninety (90) days following the giving of any such notice the Working Interest Owners have not commenced, or re-commenced, Unit Operations with a view to diligently pursuing the production of Unitized Substances on a sustained basis, the unitization provided for herein shall terminate. For purposes of this clause 1402:

(a) the term "Unit Operations" shall be construed as including only those Unit Operations involving the production of Unitized Substances on a sustained basis, and those Unit Operations of a substantive physical nature undertaken for purposes of facilitating or enhancing the production of Unitized Substances or the post-production handling of Unitized Substances;

(b) the ninety (90) day period contemplated by the second sentence of this clause 1402 shall be exclusive of any period of time during which the postponement, interruption or suspension of Unit Operations is attributable to the occurrence or subsistence of an event of force majeure contemplated by clause 1507 , and such ninety (90) day period shall be extended accordingly by any period of time following the giving of a termination notice during which the postponement, interruption or suspension of Unit Operations is so attributable; and

(c) the phrase "production of Unitized Substances on a sustained basis" shall be construed as meaning production of Unitized Substances on a substantially continuous basis, subject to normal course interruptions attributable to such factors as governmental regulation, generally accepted production optimization practices, marketing arrangements involving seasonal or other periodic interruptions in take nominations and events of force majeure contemplated by clause 1507. 
1403. Delivery of Notice

Notwithstanding the provisions of clause 1510 , no notice of a desire to terminate given under clause 1402 shall be effective unless delivered to the Unit Operator by hand or by courier, on a day on which the Unit Operator's offices at its address for service are open for regular business, and any such notice so given shall be deemed conclusively to have been given and received on the date so delivered. Forthwith upon receipt of any such notice the Unit Operator shall provide the Crown and each of the Working Interest Owners with a copy of the same, and the Working Interest Owners shall forthwith thereupon provide their Royalty Owners, other than the Crown, with a copy of the same.

1404.

\section{Salvaging Equipment Upon Termination}

Subject to any provisions to the contrary contained in any Lease or other agreement or instrument relating to the Unitized Zone or Unitized Substances, or in any surface lease agreement, easement agreement or other applicable surface rights agreement or instrument, if the Working Interest Owners fail to salvage any equipment or facilities used in Unit Operations within six (6) months of the termination of the unitization provided for herein, the Royalty Owners for each Tract upon which any such equipment or facilities are situate shall, unless any such equipment and facilities are then being used, or are expected to be used, for other operations, be entitled, but not obligated, to salvage, use, sell or otherwise dispose of such equipment and facilities for their own benefit. The six (6) month period contemplated by this clause 1404 shall be exclusive of any period of time during which the Working Interest Owners are prevented from salvaging any equipment or facilities by reason of the occurrence or subsistence of an event of force majeure contemplated by clause 1507 , and such six (6) month period shall be extended accordingly by any period of time following the termination of the unitization provided herein during which the Working Interest Owners are so prevented from salvaging any equipment or facilities.

1405.

\section{Notice to Royalty Owners}

Each of the Working Interest Owners shall within thirty (30) days of the termination of the unitization provided for herein give notice thereof to its Royalty Owners in accordance with the applicable Leases and other agreements and instruments.

\section{ARTICLE XV MISCELLANEOUS}

1501. Execution in Counterpart

This Agreement may be executed in separate counterparts, and all of the executed counterparts shall together constitute one instrument and have the same force and effect as if all of the persons executing such counterparts had executed the same instrument. 
The Unit Operator shall, upon request therefor, provide a complete set of photocopied counterpart execution pages to each Party requesting the same.

1502. Effect of Execution and Delivery

Subject to the provisions of clause 1303, this Agreement shall be binding upon a person who executes and delivers a counterpart hereof to the Unit Operator, and such person shall be bound by this Agreement as of the time of such delivery; provided, however, that if a proposed Tract fails to qualify for inclusion in the Unit Area [within the time specified in subclause 501(b), or] within the time specified by the Working Interest Owners for the purposes of a proposed enlargement under clause 1001, the Parties owning interests in such proposed Tract shall upon the expiration of such specified time be completely released from this Agreement with respect to such proposed Tract.

1503. Dual Capacity

If a Party owns a Working Interest and a Royalty Interest, its execution and delivery of a counterpart of this Agreement shall constitute execution and delivery in both capacities.

1504. Subsequent Execution

An owner of an interest in a Tract who has not executed and delivered a counterpart of this Agreement as of the date the Tract was included in the Unit Area under either Article $V$ or Article X may not thereafter become entitled to exercise the rights of a Party with respect to such interest except on such terms and conditions as may be prescribed by the Working Interest Owners.

1505.

Enurement

Subject to the provisions of clause 1201 , and to the proviso to clause 1502 , this Agreement shall enure to the benefit of, and be binding upon, the respective heirs, executors, administrators, successors and assigns of the Parties.

1506.

No Partnership

Nothing herein contained shall be read or construed as creating a partnership, or as imposing upon any Party any partnership duty, obligation or liability of any kind, it being the express intention of the Parties that the respective rights, obligations and liabilities of each of the Parties under this Agreement, and in respect of the subject matter hereof generally, shall be several, and not joint or joint and several. 
In this clause 1507 the term "event of force majeure" means any event the occurrence or subsistence of which prevents a Party from conducting Unit Operations or other operations or activities related to the subject matter of this Agreement, or from performing any obligation under this Agreement, and which is not reasonably within the control of such Party, and includes, without limitation, an act of God, a governmental directive or restriction, a labour dispute, and an act of war or other unlawful act against public order or authority, but does not include a lack of financial resources or available funds or similar financial predicament. Any Party which is at any time prevented by an event of force majeure from conducting any operation or activity, or from performing any obligation hereunder (other than an obligation to pay money), shall promptly so notify all other Parties affected thereby, providing reasonable particulars of the event of force majeure and the operation, activity or obligation the conduct or performance of which is prevented thereby, and shall take all such steps as may be reasonable in the circumstances to remedy such event of force majeure; provided, however, that no Party shall be required by the provisions hereof to settle any strike, lockout or other labour dispute on terms which it would not otherwise so settle. If any Party is at any time prevented by an event of force majeure from performing any obligation hereunder (other than an obligation to pay money), such obligation shall, to the extent that its performance is prevented by such event of force majeure, be suspended for so long as the event of force majeure continues to prevent such performance, and the non-performance of such obligation to such extent during such period of suspension shall not constitute a breach or default hereunder.

1508.

Taxes

As between the Working Interest Owners and the Royalty Owners for each Tract, all taxes levied in respect of the ownership, production or sale of the Unitized Substances associated with or allocated to such Tract shall be borne in accordance with the provisions of the applicable Lease or other agreement or instrument relating thereto. In the event that a Royalty Owner, other than the Crown, fails to pay when due any such taxes which are payable by it, the Working Interest Owners for such Tract may pay such taxes on such Royalty Owner's behalf and, without limiting any other rights of recovery which they might have, deduct the Royalty Owner's share of any payment so made from any royalty payable or deliverable to it in respect of such Tract.

1509.

Delinquent Payment Obligations

In the event that a Royalty Owner, other than the Crown, fails to pay when due any amount owing under or in respect of any mortgage, agreement for sale or other instrument or arrangement by virtue of which a third party claims an interest in a Tract, the Working Interest Owners for such Tract may, with full right of subrogation, pay such amount on such Royalty Owner's behalf and, without limiting any other rights of recovery which they might have, deduct the Royalty Owner's share of any payment so made from any royalty payable or deliverable to it in respect of such Tract. 
1510.

Notices

Except with respect to notices and communications between a Working Interest Owner and its Royalty Owners, the giving of which shall be governed by the applicable Lease or other agreement or instrument, all notices and other communications to be given in connection with this Agreement shall be in writing and shall be sufficiently given:

(a) if delivered by hand or by courier to a Party at its address for service as hereinafter provided, on any day other than a Saturday, a Sunday or a statutory holiday in Alberta;

(b) except during any period of actual or impending postal disruption, if sent by first class mail, postage prepaid, posted within Canada or the United States, to a Party at its address for service as hereinafter provided; and

(c) to any Party which has provided a direct telecommunication number as part of its address for service, if sent by telecommunication to such Party at such number on any day other than a Saturday, a Sunday or a statutory holiday in Alberta.

Any notice or communication given by delivery as aforesaid shall be deemed conclusively to have been given and received on the date of delivery, any notice or communication given by mail as aforesaid shall be deemed conclusively to have been given and received on the fourth day following the date of mailing (Saturdays, Sundays and statutory holidays in Alberta excepted), and any notice or communication given by telecommunication as aforesaid shall be deemed conclusively to have been given and received on the date on which the transmission thereof has been completed.

For the purposes of this clause 1510 , the address for service for each Party shall be the address set forth below the place of its execution of the counterpart hereof delivered to the Unit Operator. The Unit Operator may change its address for service by giving written notice thereof to each of the other Parties, and any other Party may change its address for service by giving written notice thereof to the Unit Operator. The Unit Operator shall, upon request therefor, furnish any Party with the address for service of any other Party.

1511.

Time of the Essence

Time is of the essence in this Agreement.

1512. Compliance with Laws and Regulations

In exercising their respective rights, and discharging their respective obligations, under this Agreement, the Parties shall comply in all material respects with all statutes, regulations and other lawful governmental directives from time to time in force in the 
Province of Alberta. In the event of any conflict between the provisions of this Agreement and the provisions of any such statute, regulation or other lawful governmental directive, the provisions of such statute, regulation or directive shall take precedence.

1513.

Governing Law

This Agreement shall be governed by and construed in accordance with the laws of the Province of Alberta, and each of the Parties submits to the jurisdiction of the courts of the Province of Alberta for the interpretation and enforcement hereof.

IN WITNESS WHEREOF each of the Parties has executed this Agreement on the date shown opposite its name hereunder.

DATE: 19

(NAME)

ADDRESS FOR SERVICE:

\{seal\}

\{seal \}

Fax No.

Unit Agreement (Name) 